\title{
Urban ethnobotany in Petrópolis and Nova Friburgo (Rio de Janeiro, Brazil)
}

\author{
Fernanda Leitão, ${ }^{1}$ Viviane Stern da Fonseca-Kruel, ${ }^{2}$ Inês Machline Silva, ${ }^{3}$ \\ Fernanda Reinert*,4
}

\author{
${ }^{1}$ Programa de Pós-graduação em Biotecnologia Vegetal, Universidade Federal do Rio de Janeiro, Av. Brigadeiro \\ Trompowsky s/n., Cidade Universitária 21951-590 Rio de Janeiro-RJ, Brazil, \\ ${ }_{2}^{2}$ Instituto de Pesquisas, Jardim Botânico do Rio de Janeiro, Rua Pacheco Leão 915, Jardim Botânico, 22460-030 \\ Rio de Janeiro-RJ, Brazil, \\ ${ }^{3}$ Departamento de Botânica, Universidade Federal Rural do Rio de Janeiro, Rodovia BR $465 \mathrm{Km}$ 7, 23890-000 \\ Seropédica-RJ, Brazil, \\ ${ }^{4}$ Departamento de Botânica, Instituto de Biologia, Universidade Federal do Rio de Janeiro, Av. Brigadeiro \\ Trompowsky s/n., Cidade Universitária, 21951-590 Rio de Janeiro-RJ, Brazil
}

\begin{abstract}
RESUMO: “Etnobotânica urbana em Petrópolis e Nova Friburgo (Rio de Janeiro, Brasil)”. O principal objetivo desse trabalho foi estudar as plantas úteis comercializadas em feiras livres em Petrópolis e Nova Friburgo, Rio de Janeiro, Brasil. Os dados foram coletados utilizando as técnicas de observação participante, entrevistas semi-estruturadas e listagem livre com quatro comerciantes de plantas medicinais. A partir dessas entrevistas, 115 espécies (pertencentes a 49 famílias) foram relacionadas: 94 com uso medicinal, 12 com uso religioso e 9 com uso ornamental. Trinta por cento das espécies são nativas e $72 \%$ possuem hábito herbáceo. As famílias mais representativas foram Asteraceae (26 espécies) e Lamiaceae (10 espécies). As espécies medicinais indicadas para o tratamento de doenças do sistema respiratório foram mais freqüentes durante o outono e inverno. A espécie denominada como Espinheira-santa (Clarisia $\mathrm{cf}$. ilicifolia) obteve o valor mais alto de Importância Relativa $(1,8)$ e a mais alta colocação em todas as estações do ano utilizando o cálculo Preference Ranking, embora seus níveis de eficiência e toxidez não tenham sido ainda estabelecidos. O estudo se mostrou relevante, pois visa reunir o conhecimento dos informantes sobre as espécies que comercializam em feiras livres e mercados populares no estado do Rio de Janeiro, que representa uma valiosa fonte para a bioprospecção.
\end{abstract}

Unitermos: Etnobotânica, plantas medicinais, feira-livre, conhecimento local, Brasil.

\begin{abstract}
The main goal of this paper was the study of the useful plants sold in the openair fairs of Petrópolis and Nova Friburgo, Rio de Janeiro, Brazil. Data collection was obtained through participant observation, semi structured interviews and free listing with four herbalist informants. From the interviews, 115 species (belonging to 49 families) were recorded: 94 for medicinal purposes, 12 with religious application, and 9 for ornamental purposes. Thirty percent of the species were native, and $72 \%$ herbaceous. The most representative families were Asteraceae (26 species) and Lamiaceae (10 species). The medicinal species related to diseases of the respiratory system were more common during the winter and autumn. "Espinheirasanta" (Clarisia cf. ilicifolia) had the highest Relative Importance (1.8) and collocation in all seasons using the Preference Ranking, although its effectiveness or toxicity levels have not been established. The importance of the study is to gather knowledge from local herbalists about commercialized species in open-air fairs and popular markets in the Rio de Janeiro State, which represent valuable resources for bioprospection.
\end{abstract}

Keywords: Ethnobotany, medicinal plants, herbal markets, local knowledge, Brazil.

\section{INTRODUCTION}

Studies dedicated to recover the knowledge of popular medicine have, in the last decade, received considerable attention due to the wide range of information they can provide to contemporary science
(Vendruscolo et al., 2005; Albuquerque \& Hanazaki, 2006; Silva et al., 2006; Agra et al., 2007; Rodríguez et al., 2008). According to the WHO (World Health Organization) in developing countries, about $80 \%$ of the population make use of traditional basic health care; $85 \%$ out of these use plants or their derivates 
(Vendruscolo et al., 2005; MDA, 2006; Agra et al., 2007 and 2008; Veiga-Junior, 2008).

The scientific knowledge about useful plants, particularly the ones for therapeutic use, can in turn potentially improve people's use of these plants and lifestyle, leading to an improvement of the quality of the medicinal products (Funke \& Melzig, 2006; Leitão et al., 2006; Barbosa-Filho et al., 2007; SaúdeGuimarães \& Faria, 2007; Barbosa-Filho et al., 2008). Furthermore, predatory extraction of medicinal plants has led to the reduction its natural populations (Almeida \& Albuquerque, 2002). Studies on medicinal plants that are commercialized help foster their sustainable use, encouraging the domestication and cultivation of some species (Silva et al., 2001).

Open-air fairs, which are held in public streets on fixed days of every week in each location, and popular markets, which are usually held in closed areas, consist of several stands with one or two usually with medicinal plants. Both open-air fair and markets are of especial interest to ethnobotany. There, information about the use of medicinal, ornamental and edible plants can be gathered. Research on local open-air fair and markets turned out to be indispensable for bioprospection (Martin, 2000). The studies include information about quantity, price, and seasons of availability of goods.

These studies are particularly important to countries like Brazil, where the world's largest portion of biodiversity, $15-20 \%$, is located, with emphasis on seed plants which represents about $24 \%$ of all biodiversity (MDA, 2006). This fact is associated with rich, ethnical and cultural diversity, which holds traditional and valuable knowledge regarding the uses and handling of medicinal plants.

The State of Rio de Janeiro is inside of the Atlantic Forest biome, recognized by UNESCO as one of the most critical biomes for global biodiversity conservation, where less than $8 \%$ remains from its original territory (Rambaldi et al., 2003). Rio de Janeiro holds the greatest diversity of this biome with the largest portion of preserved forest (Rambaldi et al., 2003). Additionally, in the State, there are groups of people living from subsistence agriculture in relative isolation. Such groups often possess traditional knowledge on medicinal plants (Mendonça-Filho \& Menezes, 2003; Pereira et al., 2004; Veiga-Junior, 2008).

Few ethnobotanical studies in urban environments were held in open-air fair and popular markets in Brazil (Berg, 1984; Silva et al., 2001; Almeida \& Albuquerque, 2002; Nunes et al., 2003; Pinto \& Maduro, 2003; Albuquerque et al., 2007), and to the best of our knowledge, only five studies in the State of Rio de Janeiro (Santos \& Silvestre, 2000; Stalcup, 2000; Parente \& Rosa, 2001; Azevedo \& Silva, 2006; Maioli-Azevedo \& Fonseca-Kruel, 2007) (Table 1). Our contribution is to the study of useful plants sold in the open-air fairs of Petrópolis and Nova Friburgo.
The importance of the present study is to gather knowledge from local herbalists about the species commercialized, mainly medicinal plants, in open-air fairs and popular markets in the Rio de Janeiro State.

\section{MATERIAL AND METHODS}

\section{Study area}

The present study was carried out in Petrópolis $\left(22^{\circ} 30^{\prime} 18^{\prime \prime} \mathrm{S}\right.$ e $\left.43^{\circ} 10^{\prime} 43^{\prime \prime} \mathrm{W}\right)$ and Nova Friburgo $\left(22^{\circ}\right.$ $165^{\prime}$ 'S e $42^{\circ} 31{ }^{\prime} 52^{\prime \prime} \mathrm{W}$ ), Rio de Janeiro State, Brazil, between April 2005 and February 2006. Petrópolis covers $775 \mathrm{~km}^{2}$ with ca. 306.000 habitants (IBGE, 2005), whereas Nova Friburgo covers $933 \mathrm{~km}^{2}$ and with ca. 177.000 habitants (IBGE, 2005). In Petrópolis, five popular open-air fairs (Feira do Centro, Alto da Serra, Praça Pasteur, Francisco Manoel Street, Henrique Rafaer Street) were visited, as well as the popular market, Horto-Mercado Municipal de Itaipava, of Petrópolis. In Nova Friburgo, one open-air fair (Olaria) and one popular market (Coopfeira) were visited.

\section{Methods}

During the visits to the fairs, interviews were conducted to identify and select informants in the tents which commercialized useful plants. Sampling was non-random under the assumption that local herbalists would give more specific information regarding medicinal plants. Four herbalists were interviewed, three in Petrópolis (two women - 35 and 65 years and two men - 68 and 70 years). In Nova Friburgo, only one informant was identified as a trader of useful plants; a 40 year old man.

Semi-structured forms, recorded interviews and notes were taken in the fieldwork (Alexiades, 1996). Questions were designed to obtain information concerning the availability of species at the fairs, specification of the plant parts commercialized, and the medicinal indication(s) attributed to each of them. These procedures always counted with the consent of the informants. Techniques of direct observation and free listing with informants were used to get information about the ten species more commercialized (Weller \& Kimball Romney, 1988; Bernard, 1989). The technique of free listing was repeated periodically, once every season of the year, with the same three informants resulting in a total of 12 interviews. Thus, it was possible to follow variations in the interest of consumers throughout the year.

Plants indicated by each informant were bought (whole, or in fragments - according to the sale form) and vouchers were deposited in the Herbarium of the Jardim Botânico do Rio de Janeiro (RB). The taxonomic identification of the plants was attempted following the botanical literature, comparison with other materials, 
and consultation of experts following Cronquist (1988) classification. Cited plants were assigned in one or more of the following categories: abortive, aromatic, edible, medicinal, ornamental and rituals.

Preference ranking analysis, which attributes a numerical value for each ranking position, was carried out based on the data obtained from the technique of free listing. The first plant cited received the value ten, and the forthcoming received values in descending order (Cotton, 1996; Martin, 2000). Since the information was given by more than one key informant, the final ranking of a plant for each season is the sum of values attributed according to each informant.

\section{Relative Importance (RI)}

Relative Importance (RI) calculations were performed for the species listed as medicinal plants (Bennett \& Prance, 2000). For these calculations, we considered both attributed pharmacological properties (PH) and the body system (BS), according to the international statistical classification of diseases and related to health problems (WHO, 1996).

\section{RESULTS AND DISCUSSION}

The fairs of Petrópolis and Nova Friburgo were held outdoors on the streets and squares, in one or two days a week, with tents assembled and dismantled daily. The main traded products were fruits and vegetables, dairy and poultry, produced locally (са. $80 \%$ of the stands). Only in three open-air fairs (Alto da Serra and Centro in Petrópolis and Olaria in Nova Friburgo) medicinal plants were being traded.

\section{Useful plants}

In the open-air fairs of Alto da Serra, Centro and Olaria, 115 useful plant species distributed in 49 botanical families were found (Table 2). The most representative family was Asteraceae (26 spp.), followed by Lamiaceae (10 spp.), Verbenaceae (5 spp.) and Malvaceae (4 spp.). The first two often appear as the most representative in number of species in other ethnobotanical works from Brazil (Parente \& Rosa, 2001; Di Stasi et al., 2002; Pereira et al., 2004; Gazzaneo et al., 2005; Azevedo \& Silva, 2006, Pilla et al., 2006, Pinto et al., 2006; Maioli-Azevedo \& Fonseca-Kruel, 2007). According to Di Stasi et al. (2002), these are large, mostly cosmopolitan, families (about 22.750 and 6.700 species, respectively), known worldwide as medicinal, which would explain the large number of species listed by informants in ethnobotanical works. According to Bennett \& Prance (2000), Lamiaceae, Asteraceae, Poaceae, Fabaceae and Malvaceae dominate the lists of exotic medicinal plants, being common in both temperate and tropical regions. Additionally, Asteraceae and Lamiaceae are rich in volatile oils and are widely used in popular medicine around the world (Menezes \& Kaplan, 1992; Simões \& Spitzer, 2004).

More than $30 \%$ of the species and more than $40 \%$ of popular names registered here were common to other studies conducted in Rio de Janeiro (Stalcup, 2000; Azevedo \& Silva, 2006; Maioli-Azevedo \& FonsecaKruel, 2007) (Table 1). Among the plants listed, $72 \%$ had herbaceous habit. Similar results were found in the fairs of Rio de Janeiro city (56.1\%) (Maioli-Azevedo \& Fonseca-Kruel, 2007), in the rural communities of Itacaré, Bahia (51.1\%) (Pinto et al., 2006), and in the district of Martim Francisco, Mogi-Mirim, São Paulo (57\%) (Pilla et al., 2006). Herbaceous species, used as medicinal plants, are often called therapeutic herbs because of this feature.

Of the 115 plant species cited by the informants, almost 57\% (65 species) are native of the American continent. Among the other possible origin continents, there is Asia (17 species), Europe (15), Africa (10) and Oceania (2). In another survey of plants species introduced in the indigenous pharmacopeia in the north of South America, 27\% were from Asia, 21\% from Europe and $17 \%$ from the Mediterranean region. The other centers of origin were represented by less the $15 \%$ of the plants each (Bennett \& Prance, 2000).

The informants indicated the source of most of the species mentioned (102 species). Almost half are cultivated by themselves (46\%), others were extracted from the forest (38\%), and sometimes, the same species can be either collected from the woods or cultivated (16\%). According to the available lists (IBAMA, 2002; Silva et al., 2001; Biodiversitas, 2007; CITES, 2007), none of the species cited by the informants is listed as endangered or under threat of extinction.

The most used plant parts were branches $(43 \%)$, followed by leaves (31\%), whole plants (10\%) and barks (6\%). The same was observed in other studies in Brazil (Parente \& Rosa, 2001; Di Stasi et al., 2002; Gazzaneo et al., 2005). The use of these plant parts, as opposed to roots, is more interesting from the conservation point of view, since they minimize the impact generated by extrativism, reducing the likelihood of the whole plant dying. One of the informants said: "It is good to add the root (in the tea), but to avoid killing (the plant) we do not use it”, which suggests environmental consciousness in relation to the resources.

Many medicinal species listed have multiple uses. The medicinal category was the most expressive (95 spp.), out of which, 76 were exclusively for health care. Twelve species were ascribed in the ritual category, nine as ornamental, and five each for abortive, aromatic and edible. Alecrim (Rosmarinus officinalis L., Lamiaceae), for instance, was included in three categories - medicinal, ritual and aromatic. This result can be explained by the long history of use of the species in different populations. The versatility of 
this species was also highlighted in the work of Bennett \& Prance (2000), with the indication of seventeen pharmacological properties (the largest number found in their work) for the treatment of ten body systems, reaching the second position in relative importance, second only to Plantago major L. (Plantaginaceae).

In Bolívia, the studies in open-fairs and markets revealed that the herbalists make no clear distinction between medicinal and ritual plants (Macía et al., 2005). As in Brazil, these results from the fact that, for some people or communities, the overall well-being of a person depends on both the properties of a plant and the way it is prepared and taken. Additionally, some indications are for illness that cannot be ascribed under any of the WHO categories, such as "envy" of "bad luck". Albuquerque et al. (2007) stressed the importance of open-fairs and markets as places for trading plants and products used in magical-religious rituals of AfroBrazilian cults.

\section{Relative importance (RI)}

The 95 medicinal species listed in this study were included in 16 of the 21 possible categories of the International Statistical Classification for Diseases and Related Health Problems of The World Health Organization (WHO, 1996). The category with the greatest number of species quoted was "Problems of circulatory system" (14\%), followed by "Undefined pains and illnesses" (13\%) and "Problems of the digestive system" (12\%).

In general, the use given by informants often reflects the general and the local needs. Possibly, the relatively large number of species listed for "Problems of the circulatory system" is due to the large number of people who worry about heart diseases, hypertension and high cholesterol, seeking among medicinal plants for a low cost alternative for their treatment. Since 1990, the largest cause of death in the world are the coronary diseases (Mackay \& Mensah, 2004).

The category "Undefined pains and illnesses" also had a large number of species listed, mainly because indications such as inflammation and unspecified pain and cough were included under this category. In two studies carried out in Pernambuco (Northeastern Brazil) by Gazzaneo et al. (2005) and Albuquerque et al. (2007) this category was also important.

The calculations of Relative Importance (RI) indicated Clarisia cf. ilicifolia (Spreng.) Lanj. \& Rossberg (Moraceae) as the most important species (1.8). Some species reached RI higher than 1.5: Desmodium adscendens (Sw.) DC. (Fabaceae), Echinodorus grandiflorus (Cham. \& Schltdl.) Micheli (Alismataceae), Kalanchoe brasiliensis Cambess. (Crassulaceae), Miconia chartacea Triana (Melastomataceae), Ruta graveolens L. (Rutaceae), Solidago chilensis Meyen (Asteraceae) and Struthanthus concinnus Mart. (Loranthaceae) (Table 2).

The work of Bennett \& Prance (2000) was the first to propose the RI index, surveying exotic plants from northern South America, and to include previous ethnobotanical works in the area. Some species achieved a RI greater than $70 \%$, but the only common species with the present work is Arruda (Ruta graveolens). In a study carried out in the markets of Caruaru, in the state of Pernambuco, which also presented the RI values, despite the large number of species in common with the ones surveyed here (12), the plants with the highest RI did not coincide (Almeida \& Albuquerque, 2002).

\section{Preference ranking}

We established the preference ranking using the data obtained with the free listing technique. Plants with therapeutic indications such as flu, cough, cold, lung problems and/or pneumonia, were more cited in

Table 1. Studies related to the trade of useful plants in fairs and/or markets in Brazil.

\begin{tabular}{|c|c|c|c|c|c|}
\hline Reference & Place of Study & $\begin{array}{l}\mathrm{N} . \\
\text { inf. }\end{array}$ & $\begin{array}{l}\text { N. } \\
\text { spp. }\end{array}$ & $\begin{array}{l}\text { Com. } \\
\text { Pop. }\end{array}$ & $\begin{array}{l}\text { Com } \\
\text { spp }\end{array}$ \\
\hline Berg (1984) & Ver-o- peso market, Belém, Pará & - & 167 & 9 & 8 \\
\hline Stalcup (2000) & Tijuca fairs, Rio de Janeiro, Rio de Janeiro. & 4 & 151 & 61 & 41 \\
\hline Santos \& Silvestre (2000) & $\begin{array}{l}\text { Central fairs of Rio de Janeiro city and } \\
\text { Niterói, Rio de Janeiro. }\end{array}$ & 10 & 8 & 2 & 1 \\
\hline Parente \& Rosa (2001) & Fairs of Barra do Piraí, Rio de Janeiro. & 2 & 101 & 39 & 26 \\
\hline Almeida \& Albuquerque (2002) & Fairs of Caruaru, Pernambuco. & 20 & 114 & 21 & 12 \\
\hline Pinto \& Maduro (2003) & Fair and street stends of Boa Vista, Roraima. & 5 & 100 & 24 & 9 \\
\hline Azevedo \& Silva (2006) & $\begin{array}{l}\text { Fairs and West Market, Rio de Janeiro, Rio } \\
\text { de Janeiro. }\end{array}$ & - & 127 & 57 & 39 \\
\hline $\begin{array}{l}\text { Maioli-Azevedo \& Fonseca-Kruel } \\
(2007)\end{array}$ & $\begin{array}{l}\text { South and North Fairs, Rio de Janeiro, Rio } \\
\text { de Janeiro. }\end{array}$ & 54 & 104 & 51 & 36 \\
\hline This study & $\begin{array}{l}\text { Petrópolis and Nova Friburgo, Rio de } \\
\text { Janeiro. }\end{array}$ & 5 & 115 & - & - \\
\hline
\end{tabular}

Legend - N. inf. - Number of informants. N. spp. - Number of species cited at work. Com. Pop - Number of popular names in common with this present work. Com. spp. - Number of species in common with this present work. 
Table 2. List of the plants commercialized in Petrópolis (P) and Nova Friburgo (N), Rio de Janeiro State, SE, Brazil.

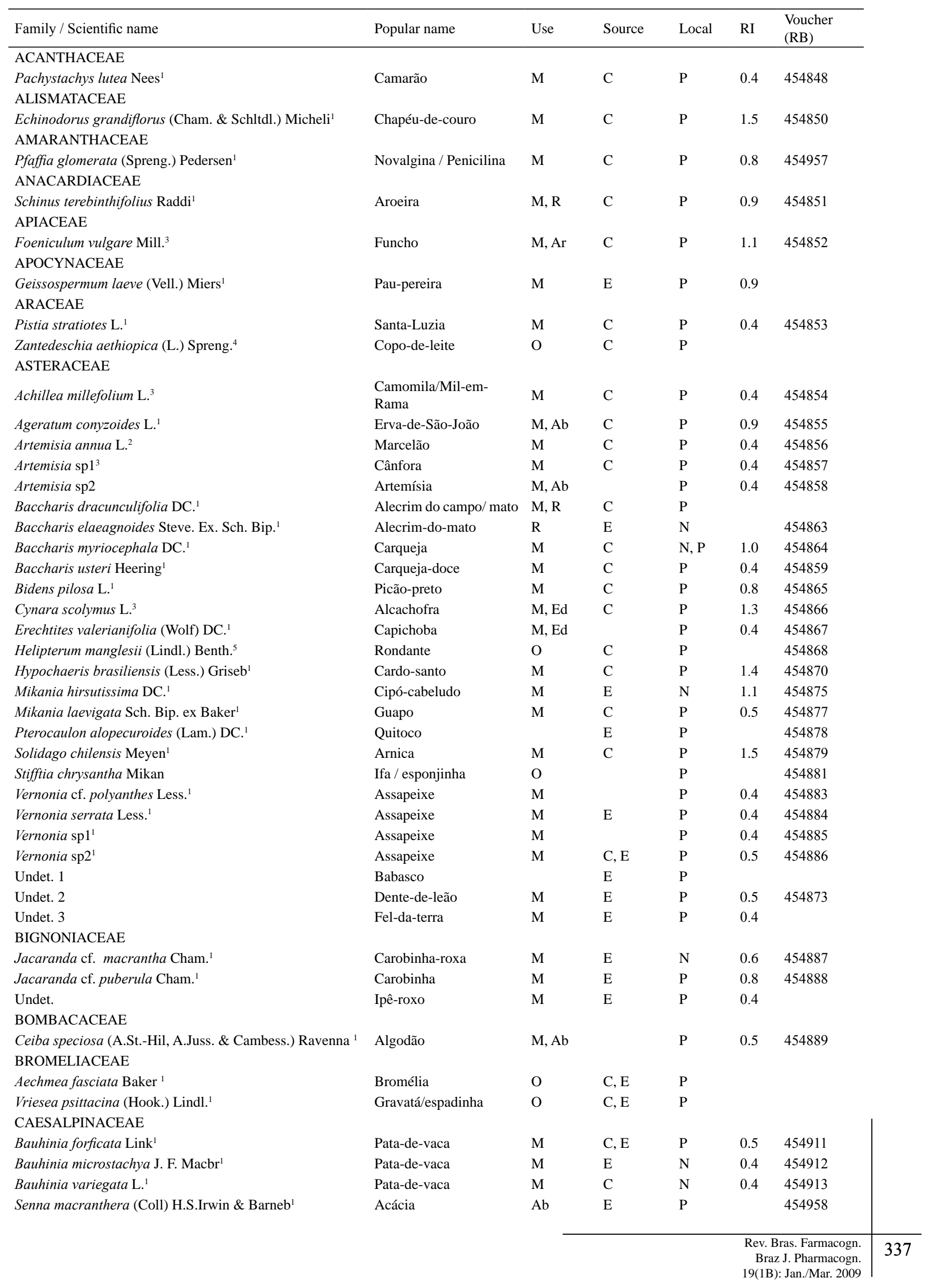




\begin{tabular}{|c|c|c|c|c|c|c|}
\hline Family / Scientific name & Popular name & Use & Source & Local & RI & $\begin{array}{l}\text { Voucher } \\
\text { (RB) }\end{array}$ \\
\hline \multicolumn{7}{|l|}{ CAPRIFOLIACEAE } \\
\hline Sambucus nigra L. ${ }^{3}$ & Sabugueiro & M & $\mathrm{C}$ & $\mathrm{P}$ & 0.5 & 454890 \\
\hline \multicolumn{7}{|l|}{ CHENOPODIACEAE } \\
\hline Chenopodium ambrosioides $\mathrm{L}^{1}$ & Santa-Maria & M & & $\mathrm{P}$ & 0.5 & 454891 \\
\hline \multicolumn{7}{|l|}{ COSTACEAE } \\
\hline Costus sp. ${ }^{1}$ & Cana-do-brejo & M & $\mathrm{C}$ & $\mathrm{P}$ & 0.4 & 454892 \\
\hline \multicolumn{7}{|l|}{ CRASSULACEAE } \\
\hline Kalanchoe brasiliensis Cambess. ${ }^{1}$ & Saião & M & $\mathrm{C}$ & $\mathrm{P}$ & 1.5 & 454893 \\
\hline \multicolumn{7}{|l|}{ CUCURBITACEAE } \\
\hline Apodanthera smilacifolia Cogn. ${ }^{1}$ & Cipó-azogue & M & $\mathrm{E}$ & $\mathrm{N}$ & 0.5 & 454894 \\
\hline Momordica charantia L..$^{2,4}$ & Melão-de-SãoCaetano & M & $\mathrm{C}$ & $\mathrm{P}$ & 0.4 & 454895 \\
\hline \multicolumn{7}{|l|}{ CUSCUTACEAE } \\
\hline $\begin{array}{l}\text { Cuscuta racemosa } \text { Mart. }^{1} \\
\text { EQUISETACEAE }\end{array}$ & Cipó-chumbinho & M & $\mathrm{E}$ & $\mathrm{P}$ & 0.4 & 454896 \\
\hline Equisetum hyemale L. ${ }^{1}$ & Cavalinha & M & $\mathrm{C}$ & $\mathrm{P}$ & 1.1 & 454897 \\
\hline \multicolumn{7}{|l|}{ EUPHORBIACEAE } \\
\hline Chamaesyce prostrata (Aiton) Small ${ }^{1}$ & $\begin{array}{l}\text { Quebra-pedra-miuda } \\
\text { roxa }\end{array}$ & $\mathrm{M}$ & $\mathrm{E}$ & $\mathrm{P}$ & 0.5 & 454898 \\
\hline \multicolumn{7}{|l|}{ FABACEAE } \\
\hline Desmodium adscendens (Sw.) DC. ${ }^{1}$ & $\begin{array}{l}\text { Amor-do-campo } \\
\text { Carrapichinho }\end{array}$ & $\mathrm{M}$ & $\mathrm{E}$ & $\mathrm{N}, \mathrm{P}$ & 1.5 & 454914 \\
\hline \multicolumn{7}{|l|}{ HELICONIACEAE } \\
\hline \multicolumn{7}{|l|}{ LAMIACEAE } \\
\hline Leonotis nepetaefolia Schimp. ex Benth. ${ }^{1,4}$ & Cordão-de-frade & & $\mathrm{C}$ & $\mathrm{P}$ & & 454900 \\
\hline Leonurus sibiricus L. $^{2}$ & Macaé & M & $\mathrm{C}, \mathrm{E}$ & $\mathrm{P}$ & 0.6 & 454901 \\
\hline Mentha pulegium $\mathrm{L}^{2,3}$ & Poejo & M & $\mathrm{C}$ & $\mathrm{P}$ & 0.4 & 454902 \\
\hline Mentha x piperita $\mathrm{L}^{3}$ & Elevante & $\mathrm{M}, \mathrm{Ab}$ & $\mathrm{C}$ & $\mathrm{P}$ & 1.0 & 454903 \\
\hline Ocimum cf. basilicum L..$^{2,4}$ & Manjericão & $\mathrm{R}, \mathrm{Ar}$ & $\mathrm{C}$ & $\mathrm{P}$ & & 454904 \\
\hline Ocimum cf. selloi Benth. ${ }^{1}$ & Alfavaca-anis & M & $\mathrm{C}$ & $\mathrm{P}$ & 0.4 & 454905 \\
\hline Ocimum gratissimum $\mathrm{L}^{2,4}$ & Alfavaca (roxa) & M & $\mathrm{C}$ & $\mathrm{P}$ & 0.8 & 454905 \\
\hline Rosmarinus officinalis $\mathrm{L}^{3}$ & Alecrim (da horta) & $\mathrm{M}, \mathrm{R}, \mathrm{Ar}$ & $\mathrm{C}$ & $\mathrm{P}$ & 0.9 & 454907 \\
\hline Salvia officinalis $\mathrm{L} .^{3}$ & Salvia & $\mathrm{M}, \mathrm{Ar}$ & $\mathrm{C}$ & $\mathrm{P}$ & 1.1 & 454908 \\
\hline Tetradenia riparia (Hochst.) L. E. Codd ${ }^{4}$ & Alfazema-fêmea & $\mathrm{R}$ & $\mathrm{C}$ & $\mathrm{P}$ & & 454909 \\
\hline \multicolumn{7}{|l|}{ LAURACEAE } \\
\hline Laurus nobilis $\mathrm{L}^{2}$ & Louro & $\mathrm{M}, \mathrm{Ar}$ & $\mathrm{C}$ & $\mathrm{P}$ & 0.4 & 454910 \\
\hline \multicolumn{7}{|l|}{ LILIACEAE } \\
\hline Aloe vera $\mathrm{L}^{2,4}$ & Babosa & M & $\mathrm{C}$ & $\mathrm{P}$ & 0.8 & 454916 \\
\hline \multicolumn{7}{|l|}{ LORANTHACEAE } \\
\hline Struthanthus concinnus Mart. ${ }^{1}$ & Erva-de-passarinho & M & $\mathrm{E}$ & $\mathrm{N}$ & 1.5 & 454917 \\
\hline \multicolumn{7}{|l|}{ LYTHRACEAE } \\
\hline $\begin{array}{l}\text { Cuphea carthagenensis (Jacq.) J. F. Macbr }{ }^{1} \\
\text { MALVACEAE }\end{array}$ & Sete-sangrias & M & $\mathrm{C}, \mathrm{E}$ & $\mathrm{N}, \mathrm{P}$ & 1.4 & 454918 \\
\hline Gossypium herbaceum $\mathrm{L} .^{4}$ & Algodão & M & & $\mathrm{P}$ & 0.4 & 454920 \\
\hline Malva parviflora $\mathrm{L}^{2,3,4}$ & Malva & M & & $\mathrm{P}$ & 1.1 & 454921 \\
\hline Malva sylvestris $\mathrm{L} .{ }^{3}$ & Malva (de banho) & M & $\mathrm{C}$ & $\mathrm{P}$ & 1.4 & 454922 \\
\hline Sida planicaulis Cav. ${ }^{1}$ & Vassoura preta & M & $\mathrm{E}$ & $\mathrm{P}$ & 0.8 & 454923 \\
\hline \multicolumn{7}{|l|}{ MELASTOMATACEAE } \\
\hline $\begin{array}{l}\text { Miconia chartacea } \text { Triana }^{1} \\
\text { MORACEAE }\end{array}$ & Branda-fogo & M & $\mathrm{E}$ & $\mathrm{P}$ & 1.5 & 454924 \\
\hline $\begin{array}{l}\text { Clarisia } \text { cf. ilicifolia (Spreng.) Lanj. \& Rossberg }{ }^{1} \\
\text { MYRTACEAE }\end{array}$ & \multicolumn{6}{|c|}{ MYRTACEAE } \\
\hline Eucalyptus globulus Labill. ${ }^{5}$ & Eucalipto & M & $\mathrm{C}, \mathrm{E}$ & $\mathrm{P}$ & 1.3 & 454927 \\
\hline Syzygium cumini (L.) Skeels ${ }^{2}$ & Jamelão & M & $\mathrm{C}$ & $\mathrm{P}$ & 0.4 & 454928 \\
\hline \multicolumn{7}{|l|}{ NYCTAGINACEAE } \\
\hline Mirabilis jalapa L. $^{1}$ & Maravilha & & & $\mathrm{P}$ & & 454929 \\
\hline ORCHIDACEAE & & & & & & \\
\hline
\end{tabular}




\begin{tabular}{|c|c|c|c|c|c|c|}
\hline Family / Scientific name & Popular name & Use & Source & Local & RI & $\begin{array}{l}\text { Voucher } \\
\text { (RB) }\end{array}$ \\
\hline Dendrobium nobile Lindl. ${ }^{2}$ & Pendoba & $\mathrm{O}$ & $\mathrm{C}$ & $\mathrm{P}$ & & \\
\hline \multicolumn{7}{|l|}{ PHYTOLACACEAE } \\
\hline Petiveria alliacea $\mathrm{L} .{ }^{1,4}$ & Guiné (piu piu) & $\mathrm{M}, \mathrm{R}$ & $\mathrm{C}$ & $\mathrm{P}$ & 0.4 & 454930 \\
\hline \multicolumn{7}{|l|}{ PIPERACEAE } \\
\hline Piper sp1 & Desata-nó & $\mathrm{M}, \mathrm{R}$ & $\mathrm{E}$ & $\mathrm{P}$ & 0.8 & 454931 \\
\hline Piper sp2 & Jaborandi & $\mathrm{M}$ & $\mathrm{E}$ & $\mathrm{N}$ & 0.4 & 454932 \\
\hline \multicolumn{7}{|l|}{ PLANTAGINACEAE } \\
\hline Plantago australis Lam. ${ }^{3}$ & Transagem & M & $\mathrm{C}, \mathrm{E}$ & $\mathrm{P}$ & 1.1 & 454933 \\
\hline Plantago major $\mathrm{L}^{2,3}$ & Transagem & M & & $\mathrm{P}$ & 1.3 & 454934 \\
\hline \multicolumn{7}{|l|}{ POACEAE } \\
\hline Coix lacryma-jobi L. ${ }^{2}$ & $\begin{array}{l}\text { Lágrima-de-Nossa- } \\
\text { Senhora }\end{array}$ & $\mathrm{M}, \mathrm{R}$ & E & $\mathrm{P}$ & 0.4 & 454935 \\
\hline Cortaderia sp. ${ }^{1}$ & Pluma & $\mathrm{O}$ & $\mathrm{C}$ & $\mathrm{P}$ & & 454936 \\
\hline Cymbopogon citratus (DC.) Stapf ${ }^{2}$ & Capim-cidreira & M & $\mathrm{C}$ & $\mathrm{P}$ & 0.5 & 454937 \\
\hline \multicolumn{7}{|l|}{ POLYGONACEAE } \\
\hline Polygonum persicaria $\mathrm{L} .{ }^{3}$ & Erva-de-bicho & M & $\mathrm{C}, \mathrm{E}$ & $\mathrm{P}$ & 1.1 & 454938 \\
\hline \multicolumn{7}{|l|}{ PTERIDACEAE } \\
\hline Adiantum raddianum $\operatorname{Pr}^{1}$ & Avenca & $\mathrm{M}, \mathrm{O}$ & $\mathrm{C}$ & $\mathrm{P}$ & 0.4 & 454939 \\
\hline \multicolumn{7}{|l|}{ ROSACEAE } \\
\hline Rosa sp..$^{2}$ & Rosa-branca & M & $\mathrm{C}$ & $\mathrm{P}$ & 0.4 & 454940 \\
\hline Rubus rosifolius $\mathrm{J}$. Smith ${ }^{1}$ & Moranguinho-do-mato & M & $\mathrm{E}$ & $\mathrm{P}$ & 0.4 & 454941 \\
\hline \multicolumn{7}{|l|}{ RUTACEAE } \\
\hline Ruta graveolens $\mathrm{L} .{ }^{3}$ & Arruda & $\mathrm{M}, \mathrm{R}$ & $\mathrm{C}$ & $\mathrm{P}$ & 1.5 & 454942 \\
\hline \multicolumn{7}{|l|}{ SCHIZAEACEAE } \\
\hline Lygodium volubile Sw. ${ }^{1}$ & Abre-caminho & $\mathrm{R}$ & $\mathrm{E}$ & $\mathrm{P}$ & & 454943 \\
\hline \multicolumn{7}{|l|}{ SOLANACEAE } \\
\hline Solanum americanum Mill. ${ }^{1}$ & Erva-moura & Ed & $\mathrm{E}$ & $\mathrm{P}$ & & 454944 \\
\hline Solanum cernuum Vell. ${ }^{1}$ & Panacéia & M & $\mathrm{E}$ & $\mathrm{P}$ & 1.1 & 454945 \\
\hline Solanum lycocarpum A. St. -Hil. ${ }^{1}$ & Fruta-de-Lobo & M & $\mathrm{E}$ & $\mathrm{P}$ & 0.4 & \\
\hline \multicolumn{7}{|l|}{ TRAPAEOLACEAE } \\
\hline Tropaeolum majus L. ${ }^{1}$ & $\begin{array}{l}\text { Chaga-de-São- } \\
\text { Sebastião/Capuchinho }\end{array}$ & M, Ed & $\mathrm{E}$ & $\mathrm{P}$ & 0.5 & 454946 \\
\hline \multicolumn{7}{|l|}{ URTICACEAE } \\
\hline Phenax sonneratii (Poir.) Wedd. ${ }^{1}$ & Paripedra/Pariataria & M & $\mathrm{C}$ & $\mathrm{P}$ & 0.5 & 454947 \\
\hline Pilea nummularifolia Griseb $^{1}$ & Dinheiro-em-penca & & $\mathrm{C}$ & $\mathrm{P}$ & & 454948 \\
\hline \multicolumn{7}{|l|}{ VERBENACEAE } \\
\hline Aloysia gratissima (Gilles \& Hook) Tronc. ${ }^{1}$ & Alfazema-macho & $\mathrm{R}$ & $\mathrm{C}$ & $\mathrm{P}$ & & 454949 \\
\hline Bouchea sp. & Gervão (roxo) & M & $\mathrm{C}$ & $\mathrm{P}$ & 0.5 & 454950 \\
\hline Lantana camara L. $^{1}$ & Cambará & $\mathrm{M}, \mathrm{R}$ & $\mathrm{E}$ & $\mathrm{P}$ & 0.4 & 454952 \\
\hline Lippia alba (Mill.) N. E. $\mathrm{Br}^{1}$ & $\begin{array}{l}\text { Capim-cidreira/Pau- } \\
\text { cidreira }\end{array}$ & M & & $\mathrm{P}$ & 0.5 & 454953 \\
\hline Stachytarpheta cayanesis Valh ${ }^{1}$ & Gervão-roxo & M & $\mathrm{C}, \mathrm{E}$ & $\mathrm{P}$ & 1.3 & 454954 \\
\hline \multicolumn{7}{|l|}{ VITACEAE } \\
\hline Cissus verticillata (L.) Nicolson \& C. E. Jarvis ${ }^{1}$ & Insulina / Mãe boa & M & & $\mathrm{P}$ & 0.8 & 454955 \\
\hline \multicolumn{7}{|l|}{ WINTERIACEAE } \\
\hline Undet. & $\begin{array}{l}\text { Casca-d'anta/Casca- } \\
\text { sagrada }\end{array}$ & M & $\mathrm{E}$ & $\mathrm{P}$ & 1.1 & \\
\hline \multicolumn{7}{|l|}{ ZINGIBERACEAE } \\
\hline Alpinia zerumbet (Pers.) B.L. Burtt. \& R.M.Sm. ${ }^{2}$ & Colônia & M & $\mathrm{C}$ & $\mathrm{P}$ & 0.4 & 454956 \\
\hline Zingiber officinale Roscoe ${ }^{1,2}$ & Gengibre & M, Ed & $\mathrm{C}$ & $\mathrm{P}$ & 0.8 & \\
\hline Undet.1 & Cipó-suma & M & $\mathrm{E}$ & $\mathrm{P}$ & 1.3 & \\
\hline Undet.2 & Cura-tombo & M & $\mathrm{E}$ & $\mathrm{N}$ & 0.5 & \\
\hline Undet.3 & Cipó-cravo & & $\mathrm{E}$ & $\mathrm{P}$ & & \\
\hline Undet.4 & Cipó-suma-roxa & M & $\mathrm{E}$ & $\mathrm{P}$ & 0.4 & \\
\hline Undet.5 & Suma-roxa & M & E & $\mathrm{P}$ & 0.4 & \\
\hline Undet.6 & Unha-de-gato & $\mathrm{M}$ & $\mathrm{E}$ & $\mathrm{P}$ & 0.6 & \\
\hline
\end{tabular}

Legend: Family / Scientific name: Continent of origin ( $\left({ }^{1}\right.$ America, ${ }^{2}$ Asia, ${ }^{3}$ Europe, ${ }^{4}$ Africa and ${ }^{5}$ Oceania); Use: M - medicinal, R ritual, O - ornamental, Ab - abortive, Ar - aromatic, Ed - edible; Source: C - Cultivated and E - Extracted; Undet. - undetermined. 
the cooler months: autumn (33\%), winter (29\%), spring $(17 \%)$ and summer $(13 \%)$. This difference confirms the idea that the plants related to "Problems of Respiratory System" are more consumed during the winter and autumn. Among these species we can highlight Saião (Kalanchoe brasiliensis), Arruda (Ruta graveolens), Poejo (Mentha pulegium L. - Lamiaceae), Cardo-santo (Hypochaeris brasiliensis (Less.) Griseb - Asteraceae), Guapo (Mikania laevigata Sch. Bip. ex Baker Asteraceae), Gengibre (Zingiber officinale Roscoe - Zingiberaceae) and Eucalipto (Eucalyptus globulus Labill. - Myrtaceae).

The Espinheira-santa (Clarisia cf. ilicifolia) was the first in all seasons. This species was indicated for the treatment of the digestive system such as gastritis, heartburn, ulcers, general stomach problems, and also to treat diabetes and high blood pressure and weight loss. These health problems are not season-related, which might explain why its citation frequency did not change. However, the recognized species by the Ministry of Health (Coulaud-Cunha et al., 2004) as Espinheira-santa is Maytenus ilicifolia Mart. ex. Reiss (Celastraceae) (Carvalho et al., 2008). The use of other species as Espinheira-santa was reported before. Some examples are: Sorocea bonplandii Bailon (Moraceae) (Parente \& Rosa, 2001; Coulaud-Cunha et al., 2004), $S$. guilleminiana Gaudich (Moraceae) (Azevedo \& Silva, 2006; Maioli-Azevedo \& Fonseca-Kruel, 2007), S. ilicifolia Miq. (Moraceae) (Di Stasi et al., 2002), and Zollernia ilicifolia Vog. (Fabaceae) (Coelho et al., 2003). This confusion is related to the fact that these species share some phenotypic characteristics.

Coulaud-Cunha et al. (2004) interviewed 28 medicinal plant vendors in Rio de Janeiro, and all of them commercialized Sorocea bonplandii as Espinheirasanta. According to these authors, there are no studies to ensure the lack of chronic toxicity of this species, which may be a risk to consumers. Coelho et al. (2003) observed chemical differences between Zollernia ilicifolia and the two kinds of Maytenus investigated (M. ilicifolia and M. aquifolium). They observed the presence of one cyanogenic glicosyde in Z. ilicifolia, which, according to researchers, warns against the misuse of this Espinheira-santa.

The number of species erroneously used as Espinheira-santa plus its high frequency of citation make phytochemical and pharmacological studies highly necessary to ensure that this Espinheira-santa is safe to be used as a medicinal and that it posses the medicinal properties accredited to it.

\section{CONCLUSION}

The informants from the open-fairs of Petrópolis and Nova Friburgo have the knowledge about the use of the plants they trade, especially the medicinal plants. They also presented some level of environmental consciousness in the conservation of plant resources, preferring use of branches and leaves. The medicinal species related to diseases of the respiratory system were more common in the cooler seasons (autumn and winter) and the species more often quoted in all seasons, Espinheira-santa (Clarisia cf. ilicifolia), does not have its effectiveness or its levels of toxicity evaluated. Because of the large number of commercialized species, further surveys will be necessary to broaden our knowledge of the universe of plants commercialized in the State of Rio de Janeiro.

\section{ACKNOWLEDGEMENTS}

The authors wish to acknowledge the herbalists for the receptivity during the fieldwork, and the CNPq for funding the work of F. L. Santos.

\section{REFERENCES}

Agra MF, França PF, Barbosa-Filho JM 2007. Synopsis of the plants known as medicinal and poisonous in Northeast of Brazil. Rev Bras Farmacogn 17: 114140.

Agra MF, Silva KN, Basílio IJLD, França PF, Barbosa-Filho JM 2008. Survey of medicinal plants used in the region Northeast of Brazil. Rev Bras Farmacogn 18: 472-508.

Albuquerque UP, Hanazaki N 2006. As pesquisas etnodirigidas na descoberta de novos fármacos de interesse médico e farmacêutico: fragilidades e pespectivas. Rev Bras Farmacogn 16 (Supl.): 678-689.

Albuquerque UP, Monteiro JM, Ramos MA, Amorim ELC 2007. Medicinal and magic plants from a public market in northeastern Brazil. J Ethnopharmacol 110: 76-91.

Alexiades MN 1996. Selected guidelines for ethnobotanical research: a field manual. New York: The New York Botanical Garden.

Almeida CFCB, Albuquerque UP 2002. Uso e conservação de plantas e animais medicinais no estado de Pernambuco (Nordeste do Brasil): um estudo de caso. Interciência 26: 276-285.

Azevedo SKS, Silva IM 2006. Plantas medicinais e de uso religioso comercializadas em mercados e feiras livres do Rio de Janeiro, RJ, Brasil. Acta Bot Bras 20: 185-194.

Barbosa-Filho JM, Nascimento-Júnior FA, Tomaz ACA, Athayde-Filho PF, Silva MS, Cunha EVL, Souza MFV, Batista LM, Diniz MFFM 2007. Natural products with antileprotic activity. Rev Bras Farmacogn 17: 141-148.

Barbosa-Filho JM, Alencar AA, Nunes XP, Tomaz ACA, Sena-Filho JG, Athayde-Filho PF, Silva MS, Souza MFV, da-Cunha EVL 2008. Sources of alpha-, beta, gamma-, delta- and epsilon-carotenes: A twentieth century review. Rev Bras Farmacogn 18: 135-154.

Bennett BC, Prance G 2000. Introduced plants in the indigenous pharmacopoeia of Northern South America. Econ Bot 54: 90-102.

Berg MEVD 1984. Ver-o-peso: The Ethnobotany of an 
Amazonian market. In: Prance GT, Kallunki Advances in Economic Botany. vol.1. The New York Botanical Garden, New York.

Bernard RH 1989. Research methods in cultural anthropology. Londres: SAGE Publications.

Biodiversitas 2007. www.biodiversitas.org.br/floraBr/iucn. pdf. Accessed in June 18th, 2007.

Carvalho ACB, Balbino EE, Maciel A, Perfeito JPS 2008. Situação do registro de medicamentos fitoterápicos no Brasil. Rev Bras Farmacogn 18: 314-319.

CITES 2007. Convention on International Trade in Endangered Species of Wild Fauna and Flora. Appendices I, II and III. - http://www.cites.org/eng/app/appendices. shtml. Accessed in June 18th, 2007.

Coelho RG, Di Stasi LC, Vilegas W 2003. Chemical constituents from the infusion of Zollernia ilicifolia Vog and comparision with Maytenus species. Z Naturforsch 58c: 47-52.

Cotton CM 1996. Ethnobotany: principles and applications. John Wiley and Sons, England.

Coulaud-Cunha S, Oliveira RS, Waissmann W 2004. Venda livre de Sorocea bonplandii Bailon como Espinheira Santa no município do Rio de Janeiro, RJ. Rev Bras Farmacogn 14: 51-53.

Cronquist A 1988. The evolution and classification of flowering plants. 2nd Ed. New York: New York Botanical Garden.

Di Stasi LC, Oliveira GP, Carvalhaes MA, Queiroz-Junior M, Tien OS, Kakinami SH, Reis MS 2002. Medicinal plants popularly used in the Brazilian Tropical Atlantic Forest. Fitoterapia 73: 69-91.

Funke I, Melzig MF 2006. Traditionally used plants in diabetes therapy - phytotherapeutics as inhibitors of $\alpha$-amylase activity. Rev Bras Farmacogn 16: 1-5.

Gazzaneo LRS, Lucena RFP, Albuquerque UP 2005. Knowledge and use of medicinal plants by local specialists in an region of Atlantic Forest in the state of Pernambuco (Northeastern Brazil). J Ethnobiol Ethnomed 1: 9.

IBAMA 2002. Lista Oficial de Flora Ameaçada de Extinção. Portaria No 37-N, de 3 de abril de 1992. www.ibama. gov.br/flora/extincao.htm. Accessed in October 27th, 2006.

IBGE 2005. www.ibge.gov.br/cidadesat/default.php. Accessed in November 21st, 2006.

Leitão SG, Castro O, Fonseca EM, Julião LS, Tavares ES, Leo RRT, Vieira RC, Oliveira DR, Leitão GG, Martino V, Sulsen V, Barbosa YAG, Pinheiro DPG, Silva PEA, Teixeira DF, Lourenço MCS 2006. Screening of Central and South American plant extracts for antimycobacterial activity by the Alamar Blue test. Rev Bras Farmacogn 16: 6-11.

Macía MJ, García E, Vidaurre PJ 2005. An ethnobotanical survey of medicinal plants commercialized in the markets of $\mathrm{La} \mathrm{Paz}$ and El Alto, Bolivia. $J$ Ethnopharmacol 97: 337-350.

Mackay J, Mensah G 2004. The Atlas of Heart Disease and Strok. http://www.who.int/cardiovascular_diseases. Accessed in October 3rd, 2006.

Maioli-Azevedo V, Fonseca-Kruel V 2007. Plantas medicinais e ritualísticas vendidas em feiras livres no município do Rio de Janeiro, RJ, Brasil: estudo de caso nas zonas Norte e Sul. Acta Bot Bras 21: 263-275.
Martin GJ 2000. Etnobotánica - Manual de métodos: manuales de conservación. Série Pueblos y Plantas 1, WWF. Ed. Nordan-Comunidad, Uruguay.

MDA 2006. http://www.mda.gov.br/saf/arquivos/0950311751. doc. Accessed in May 30th, 2007.

Mendonça-Filho RFW, Menezes FS 2003. Estudo da utilização de plantas medicinais pela população da Ilha GrandeRJ. Rev Bras Farmacogn 13 (Supl): 55-58.

Menezes FS, Kaplan MAC 1992. Plantas da subfamília Ocimoideae utilizadas na medicina popular: Etnofarmacologia vc Química. Rev Bras Farm 73: 30-31.

Nunes GP, Silva MF, Resende UM, Siqueira JM 2003. Plantas medicinais comercializadas por raizeiros no Centro de Campo Grande, Mato Grosso do Sul. Rev Bras Farmacogn 13: 83-92.

Parente CET, Rosa MMT 2001. Plantas comercializadas como medicinais no Município de Barra do Piraí, RJ. Rodriguésia 52: 47-59.

Pereira RC, Oliveira MTR, Lemos GCS 2004. Plantas utilizadas como medicinais no município de Campos de Goytacazes - RJ. Rev Bras Farmacogn 14 (Supl.1): 37-40.

Pilla MAC, Amorozo MCM, Furlan A 2006. Obtenção e uso das plantas medicinais no distrito de Martim Francisco, Município de Mogi-Mirim, SP, Brasil. Acta Bot Bras 20: 789-802.

Pinto AAC, Maduro CB 2003. Produtos e subprodutos da medicina popular comercializados na cidade de Boa Vista, Roraima. Acta Amazônica 33: 281-290.

Pinto EPP, Amorozo MCM, Furlan A 2006. Conhecimento popular sobre plantas medicinais em comunidades rurais de mata atlântica - Itacaré, BA, Brasil. Acta Bot Bras 20: 751-762.

Rambaldi DM, Magnani A, Ilha A, Lardosa E, Figueiredo P, Oliveira RF 2003. A Reserva da Biosfera da Mata Atlântica no Estado do Rio de Janeiro. Caderno 22. Caderno da Reserva da Biosfera da Mata Atlântica Programa MAB. Cetesb, São Paulo.

Rodríguez M, Hasegawa M, González-Mújica F, Motta N, Castillo A, Castillo J, Zea E, Mora K, Sousa L, González A, Camejo D 2008. Antidiabetic and antiradical activities of plants from Venezuelan Amazon. Rev Bras Farmacogn 18: 331-338.

Santos MG, Silvestre LS 2000. Pteridófitas comercializadas por erveiros de Niterói e do Rio de Janeiro, RJ, Brasil: Uma abordagem etnobotânica. Leandra 15: 79-90.

Saúde-Guimarães DA, Faria AR 2007. Substâncias da natureza com atividade anti-Trypanosoma cruzi. Rev Bras Farmacogn 17: 455-465.

Silva SR, Buitron X, Oliveira LH, Martins MV 2001. Plantas medicinais do Brasil: aspectos gerais sobre legislação e comércio. TRAFFIC América do SulIBAMA, Equador.

Silva MIG, Gondim APS, Nunes IFS, Sousa FCF 2006. Utilização de fitoterápicos nas unidades básicas de atenção à saúde da família no município de Maracanaú (CE). Rev Bras Farmacogn 16: 455-462.

Simões CMO, Spitzer V 2004. Óleos Voláteis. In. Simões MO et al. (org.). Farmacognosia: da planta ao medicamento. Porto Alegre/Florianópolis: Ed. UFRGS/Ed. UFSC. 
Stalcup MM 2000. Plantas de uso medicinal ou ritual numa feira livre no Rio de Janeiro, Brasil. Dissertação de Mestrado da Pós-Graduação em Ciências Biológicas, UFRJ.

Veiga-Junior VF 2008. Estudo do consumo de plantas medicinais na Região Centro-Norte do Estado do Rio de Janeiro: aceitação pelos profissionais de saúde e modo de uso pela população. Rev Bras Farmacogn 18: 308-313.

Vendruscolo GS, Rates SMK, Mentz LA 2005. Dados químicos e farmacológicos sobre as plantas utilizadas como medicinais pela comunidade do bairro Ponta Grossa, Porto Alegre, Rio Grande do Sul. Rev Bras Farmacogn 15: 361-372.

Weller SC, Kimball Romney A 1988. Systematic data collection. SAGE. Newbury CA.

WHO 1996. World Health Organization. Classificação estatística internacional de doenças e problemas relacionados à saúde. Www.datasus.gov.br/cid10/ webhelp/cid10.htm. Accessed in August 16th, 2006. 